\title{
Tubercular Ulcer: Not so Uncommon Cause of Odynophagia
}

\section{Manoj Kohle ${ }^{1}$ Vikas Singla ${ }^{2}$ Shivam Khare ${ }^{1} \quad$ Nishant Wadhwa $^{3} \quad$ Pooja Bakshi $^{4} \quad$ Anil Arora $^{5}$}

${ }^{1}$ Institute of Liver, Gastroenterology and Pancreaticobiliary Sciences, Sir Ganga Ram Hospital, New Delhi, India

2Department of Gastroenterology, Sir Ganga Ram Hospital, New Delhi, India

${ }^{3}$ Department of Paediatrics, Sir Ganga Ram Hospital, New Delhi, India

${ }^{4}$ Department of Cytopathology, Sir Ganga Ram Hospital, New Delhi, India

J Digest Endosc:2020;11:297-297

These images are from a 13-year-old girl, who presented with odynophagia. Upper gastrointestinal (GI) endoscopy revealed longitudinal ulcer in the mid esophagus ( - Fig. 1). CT chest -Fig. 2 and endoscopic ultrasound (EUS) (-Fig. 3) showed a node in the left paratracheal region. Cytology examination showed necrotic granulomas ( - Fig. 4 ), and stain for acid-fast

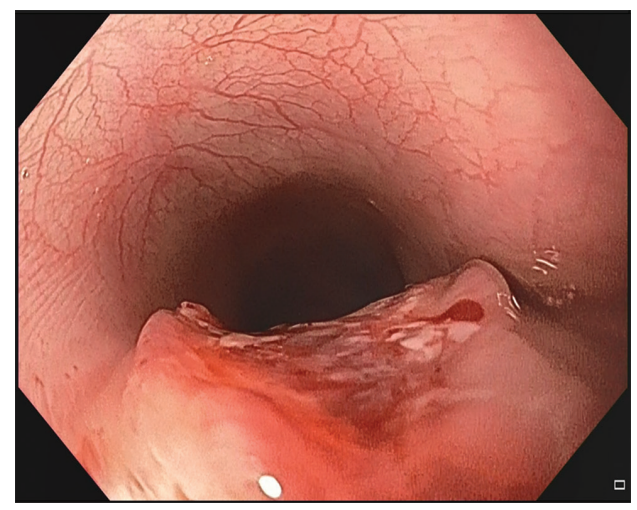

Fig. 1 Longitudinal ulcer in the esophagus over the underlying bulge.

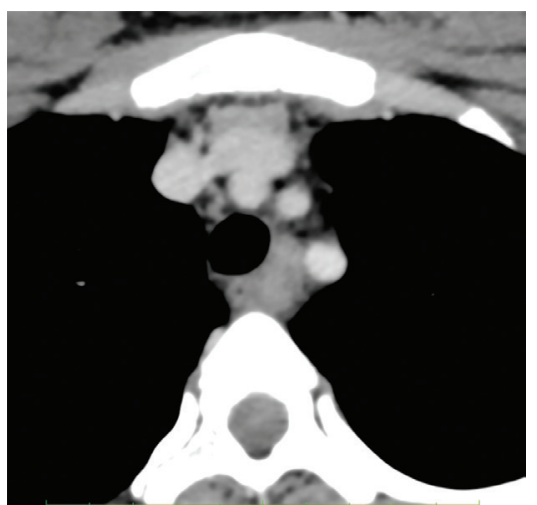

Fig. 2 CT image of the chest showing enlarged node in left lower paratracheal region.
Address for correspondence Vikas Singla, DM, Department of Gastroenterology, Sir Ganga Ram Hospital, New Delhi, India (e-mail: singlavikas1979@gmail.com).

\section{${ }^{5}$ Department of Gastroenterology and Hepatology, Sir Gangaram Hospital, New Delhi, India}

bacillus (AFB) was positive. Midesophageal ulcers have varied etiology such as viral diseases, pill esophagitis, corrosive injury, submucosal lesions, or malignancy. In endemic places, tuberculosis should be considered as differential diagnosis. Subepithelial bulge with ulcer (summit ulcer) has been explained in tuberculosis.

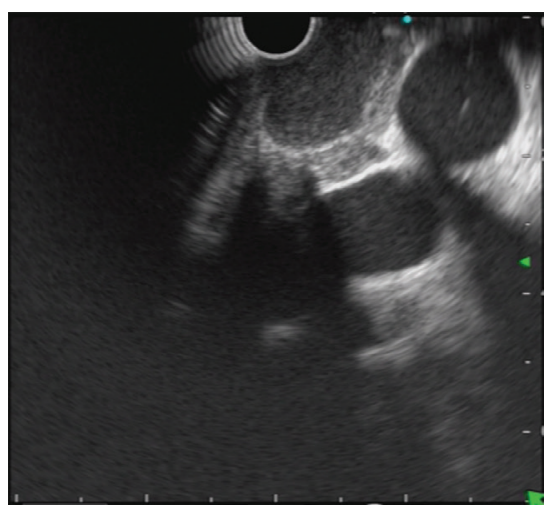

Fig. 3 Endoscopic ultrasound examination from mid esophagus showing homogeneous hypoechoic node in left lower paratracheal region.

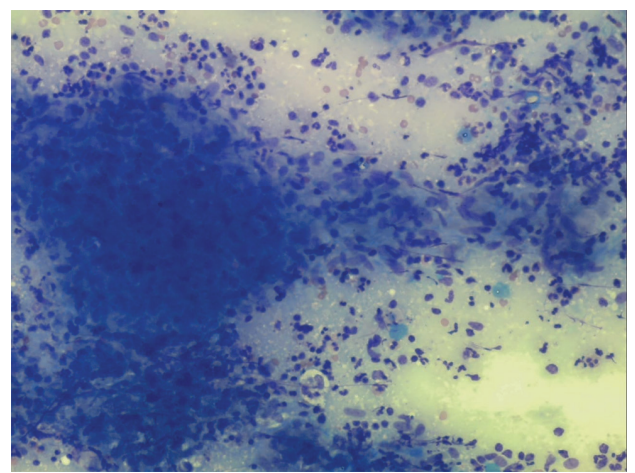

Fig. 4 Cytology examination of the EUS FNA sample showing epithelioid granuloma, MGG stain, 20X.

(c) 2020. Society of Gastrointestinal Endoscopy of India.

This is an open access article published by Thieme under the terms of the Creative Commons Attribution-NonDerivative-NonCommercial-License, permitting copying and reproduction so long as the original work is given appropriate credit. Contents may not be used for commercial purposes, or adapted, remixed, transformed or built upon. (https://creativecommons.org/licenses/by-nc-nd/4.0/).

Thieme Medical and Scientific Publishers Pvt. Ltd. A-12, 2nd Floor, Sector 2, Noida-201301 UP, India 